\title{
Transposon Tn5 Mutagenesis of Genes Encoding Reaction Centre and Light-harvesting LH1 Polypeptides of Rhodobacter sphaeroides
}

\author{
By C. NEIL HUNTER \\ Department of Pure and Applied Biology, Imperial College, Prince Consort Road, \\ London SW7 2BB, UK
}

(Received 24 November 1987; revised 1 February 1988)

\begin{abstract}
The puf operon of the photosynthetic bacterium Rhodobacter sphaeroides encodes reaction centre and B875 (LH1) antenna polypeptides of the photosynthetic apparatus. This region of the genome was used to establish the applicability of random transposon Tn5 mutagenesis in this bacterium. Four Tn 5 insertions have been mapped and one of the mutants characterized using a variety of techniques in order to establish that the fluorescence properties and polypeptide composition were consistent with the absence of reaction centre polypeptides. Following the 'rescue' of the transposon along with flanking regions of the puf operon, re-introduction of this construction into wild-type $R b$. sphaeroides yielded the original mutation. This demonstrates that following homologous recombination, localized mutagenesis can direct $\operatorname{Tn} 5$ into a predetermined region of the $R b$. sphaeroides chromosome. Accordingly, puf genes borne on plasmid pSRC2 were mutagenized with Tn5 in Escherichia coli, and the sites of insertion mapped physically. pSRC2 derivatives containing Tn5 were transferred to wild-type $R b$. sphaeroides. puf genes have been mapped by correlating the photosynthetic properties of resulting strains with the sites of $\mathrm{Tn} 5$ insertion into $\mathrm{pSRC} 2$.
\end{abstract}

\section{INTRODUCTION}

Rhodobacter sphaeroides is a photosynthetic bacterium which has found widespread use as a model system for the study of light-harvesting processes and of the subsequent charge separation within the reaction centre. Furthermore, it is able to grow either aerobically in the dark or photosynthetically in anaerobic conditions, and so this bacterium, together with Rhodobacter capsulatus, has been extremely useful to workers interested in the biogenesis of photosynthetic membranes. A variety of genetic tools have been available to those who use $R b$. capsulatus, including vector mobilization techniques, lac transcriptional fusions, and chromosomal mapping techniques (Taylor et al., 1983; Biel \& Marrs, 1983; Willison et al., 1985). In $R b$. sphaeroides, these tools are also available (Zinchenko et al., 1984; Nano et al., 1984; Pemberton \& Bowen, 1981) in addition to a transformation system (Fornari \& Kaplan, 1982) and an in vitro transcription-translation system (Chory \& Kaplan, 1982). In view of the usefulness of transposon Tn 5 mutagenesis as a method of generating maps of chromosomal genes in many bacteria (reviewed by de Bruijn \& Lupski, 1984), and of the application of similar techniques to Rb. capsulatus (Youvan et al., 1982; Zsebo \& Hearst, 1984; Kaufmann et al., 1984), this work set out to establish $\operatorname{Tn} 5$ mutagenesis as an additional way of investigating genes of $R b$. sphaeroides.

This study concentrates on the puf operon of $R b$. sphaeroides, which encodes the $\alpha$ and $\beta$ polypeptides of the B875 (light-harvesting 1, or LH1) complex and the $\mathrm{L}$ and $\mathrm{M}$ polypeptides of the reaction centre complex. This operon has been studied in some detail (Zhu et al., 1986), and the availability of sequence data, together with a restriction map (Williams et al., 1983, 1984; Hunter et al., 1987), makes it a suitably well-characterized target for transposon mutagenesis. Moreover, earlier work by Youvan et al. (1983) suggested that mutagenesis of this operon would result in an easily detectable, highly fluorescent phenotype: in such mutants, light energy 
Table 1. Bacterial strains and plasmids

\begin{tabular}{|c|c|c|c|}
\hline Strain or plasmid & Relevant characteristics & Source* & Reference \\
\hline $\begin{array}{l}\text { E. coli } \\
\text { S17-1 }\end{array}$ & $\begin{array}{l}\mathrm{RP} 4-2(\mathrm{Tc}:: \mathrm{Mu}, \mathrm{Km}:: \mathrm{Tn} 7) \text { integrated } \\
\text { into the chromosome; thi pro hsdR } \\
h s d M^{+} \operatorname{rec} A \mathrm{Tp}^{\mathrm{R}} \mathrm{Sm}^{\mathrm{R}}\end{array}$ & R.S. & Simon et al. (1983) \\
\hline $\begin{array}{l}\text { C600:: Tn5 } \\
\text { HB101 }\end{array}$ & $\begin{array}{l}\text { thi thr leu tonA lacY supE } \mathrm{Km}^{\mathrm{R}} \\
\text { thi pro hsdR hsdM recA leuB lacZ supE } \\
\text { tonA } \mathrm{Sm}^{\mathrm{R}}\end{array}$ & F.C.H.F. & Boyer \& Roulland-Dussoix (1969) \\
\hline DH1 & $\mathrm{F}^{-} \operatorname{rec} A$ end $A$ gyrA thi- 1 hsdR supE & G.T. & Hanahan (1983) \\
\hline $\begin{array}{l}R b . \text { sphaeroides } \\
\text { NCIB } 8253\end{array}$ & Wild-type & R.A.N. & \\
\hline $\begin{array}{l}\text { Plasmids } \\
\text { pSUP202 }\end{array}$ & $\underset{\text { replicon }}{\mathrm{Ap}^{\mathrm{R}} \mathrm{Tc}^{\mathrm{R}} \mathrm{Cm}^{\mathrm{R}} ; \mathrm{Mob}^{+} \mathrm{Tra}^{-} ; \text {ColE1 }}$ & R.S. & Simon et al. (1983) \\
\hline $\begin{array}{l}\text { pSUP2021 } \\
\text { pAcYc184 }\end{array}$ & $\begin{array}{l}\text { pSUP202::Tn5; Km }{ }^{R} \\
\operatorname{Tc}^{R} C_{m^{R}}\end{array}$ & R.S. & $\begin{array}{l}\text { Simon et al. }(1983) \\
\text { Chang \& Cohen (1978) }\end{array}$ \\
\hline $\begin{array}{l}\text { pRK2073 } \\
\text { pJW1 }\end{array}$ & $\begin{array}{l}\mathrm{Sp}^{\mathrm{R}} \text {; } \mathrm{Tra}^{+} \mathrm{Mob}^{+} \text {; ColEl replicon } \\
\mathrm{Ap}^{\mathrm{R}} ; 12 \cdot 2 \mathrm{~kb} \text { fragment bearing puf } \\
\text { genes cloned into BamHI site of } \\
\text { pBR322 }\end{array}$ & $\begin{array}{l}\text { M.J.D. } \\
\text { J.C.W. }\end{array}$ & Leong et al. (1982) \\
\hline pSRC2 & $\begin{array}{l}\mathrm{Ap}^{\mathrm{R}} \mathrm{Cm}^{\mathrm{R}} ; 7.2 \mathrm{~kb} \text { Bam HI-HindIII frag- } \\
\text { ment of pJW1 cloned into pSUP202 }\end{array}$ & & Hunter \& Turner (1988) \\
\hline pKan2 & $\begin{array}{l}\text { Ap }{ }^{\mathrm{R}} ; 3.5 \mathrm{~kb} \text { HindlII fragment of } \operatorname{Tn} 5 \\
\text { cloned into pBR322 }\end{array}$ & J.B. & \\
\hline $\operatorname{pSRC1}:: \operatorname{Tn} 5: 9$ & $\begin{array}{l}\mathrm{Ap}^{\mathrm{R}} \mathrm{Tc}^{\mathrm{R}} ; 11 \cdot 2 \mathrm{~kb} \text { Eco } \mathrm{RI} \text { fragment bear- } \\
\text { ing puf genes and Tn } 5 \text { insert; obtained } \\
\text { by rescue from mutant TNF9 }\end{array}$ & & This work \\
\hline
\end{tabular}

* R.S., Dr R. Simon, University of Bielefeld, FRG; F.C.H.F., Dr F.C.H. Franklin, University of Birmingham, UK; G.T., Dr G. Turner, University of Bristol, UK; R.A.N., Professor R.A. Niederman, Rutgers University, NJ, USA; M. J.D., Dr M. J. Daniels, John Innes Research Institute, UK; J. C. W., Dr J. C. Williams, Du Pont Research, Delaware, USA; J.B., Professor J. Beringer, University of Bristol, UK.

harvested by the LH2 (B800-850) complex cannot transfer to the photochemical reaction centre and is re-emitted as fluorescence. In this paper, it is demonstrated that the $\mathrm{Tn} 5$ mutagenesis system of Simon et al. (1983) is applicable to $R b$. sphaeroides; $\operatorname{Tn} 5$ insertions into the puf $L$ and $M$ genes have been mapped and one of these has been re-introduced into the wild-type. Following homologous recombination, this process of 'localized' mutagenesis (Simon et al., 1983) produces the original $\operatorname{Tn} 5$ insertion and phenotype. Further $\operatorname{Tn} 5$ insertions were used to map puf genes essential for photosynthetic growth.

\section{METHODS}

Microbiological methods. Bacterial strains and plasmids are listed in Table 1. Escherichia coli strains were grown on LB medium. $R b$. sphaeroides was grown on M22 medium (Sistrom, 1977) supplemented with sodium succinate $\left(4.6 \mathrm{~g} \mathrm{l}^{-1}\right)$, sodium glutamate $\left(0.27 \mathrm{~g}^{-1}\right)$ and aspartic acid $\left(0.04 \mathrm{~g} \mathrm{l}^{-1}\right)$. This is designated M22+.

Antibiotics were used at the following concentrations $\left(\mu \mathrm{g} \mathrm{ml}^{-1}\right)$ : for $E$. coli, neomycin 30, tetracycline 10 , streptomycin 25 or 500 , ampicillin 50 , spectinomycin 50 ; for $R b$. sphaeroides, kanamycin 20 , neomycin 20 , streptomycin 50.

Preparation and analysis of DNA and RNA. The methods are described in the preceding paper (Hunter \& Turner, 1988).

Conjugative crosses. (i) E. coli/Rb. sphaeroides. Donor and recipient cells were washed once in LB medium and mixed in the ratio $1: 20$ with the $\mathrm{OD}_{680}=2$. A $50 \mu 1$ sample was placed onto a well-dried plate of $L B$ agar and left for 4-8 h at $32{ }^{\circ} \mathrm{C}$. The mixture was harvested, washed once in M22 + plates supplemented with neomycin.

(ii) E. coli/E. coli. Donor and recipient cells were washed once in LB medium and mixed in the ratio $1: 1$. After $4 \mathrm{~h}$ at $37^{\circ} \mathrm{C}$ on a well-dried plate of LB agar the mixture was harvested and plated on selective medium.

Low-temperature spectroscopy. This was performed as described previously (Kramer \& Amesz, 1982).

$S D S-P A G E$. This was done using the buffer system described by Laemmli (1970) with an $11 \cdot 5-16 \cdot 5 \%(\mathrm{w} / \mathrm{v})$ gradient of acrylamide.

Fluorescence photography. This was performed essentially as described by Youvan et al. (1983). 

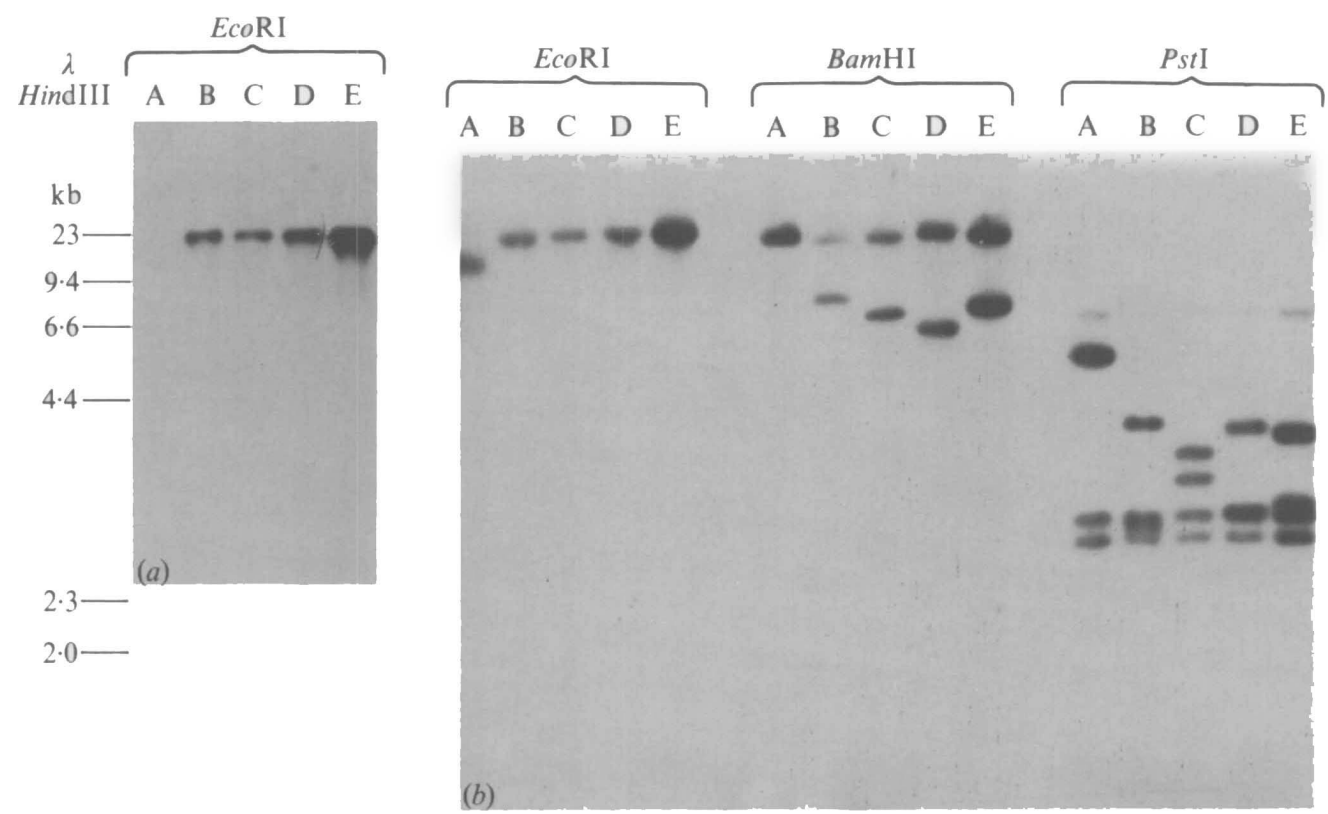

Fig. 1. Southern blot of genomic DNA prepared from wild-type and mutant strains of $R \boldsymbol{b}$. sphaeroides. Tracks: A, wild-type; B, C, D, E, non-photosynthetic strains TNF 9, 10, 11, 26, respectively. Conditions for DNA electrophoresis, blotting and labelling are described in Methods. $(a)$ Probed with pKan2, which contains cloned Tn5 DNA; (b) probed with pJW1, which contains cloned puf genes. Several PstI fragments in wild-type genomic DNA are not shown here because of their small size and weak hybridization.

\section{RESULTS}

Following conjugative transfer of pSUP2021 from $E$. coli the frequency with which neomycin resistance was acquired by $R b$. sphaeroides was $2.3 \times 10^{-6}$ per recipient, over an average of twelve experiments. Fifty neomycin-resistant colonies were selected at random: in 48 cases, 'suicide' of the pSUP202 vector must have occurred since no signals were detected in hybridization analyses with radiolabelled pSUP202 as a probe. This vector is therefore not maintained in $R b$. sphaeroides; such instability has been noted in many other Gram-negative bacteria (Simon et al., 1983).

A total of approximately 13000 neomycin-resistant colonies of $R b$. sphaeroides were generated, and among these, 31 were found to be highly fluorescent, according to the criteria of Youvan et al. (1983), in which high-speed infra-red photography detects enhanced levels of fluorescence emitted at around $900 \mathrm{~nm}$ from colonies of photosynthetically defective mutants. After purification and rechecking for fluorescence, for inability to photosynthesize, and for 'suicide' of the pSUP202 vector, genomic DNA was prepared from half of the mutants in order that the site of insertion of Tn5 could be investigated. It is known that the puf operon of $R b$. sphaeroides is located within an $11.2 \mathrm{~kb}$ EcoRI fragment; insertion of Tn5 (5.7 kb; Jorgensen et al., 1979) would increase the size of the EcoRI fragment hybridizing with an appropriate probe, pJW1, which contains cloned puf genes. In this experiment, it was found that in approximately one-third of these mutants the highly fluorescent phenotype had arisen as a result of Tn5 insertion into the puf operon, but in many other cases insertion into other genes such as puhA, which encodes the reaction centre $\mathrm{H}$ subunit (Donohue et al., 1986), could give the same phenotype (Zsebo \& Hearst, 1984; C. N. Hunter, unpublished results). The following studies were confined to insertions into the puf operon, since this provides a relatively well-defined system in which to examine $\mathrm{Tn} 5$ mutagenesis.

Genomic DNA from the wild-type and four mutants was digested with various restriction endonucleases in order to investigate the site of insertion of Tn 5 (Fig. 1). Firstly, the presence of 
(a)

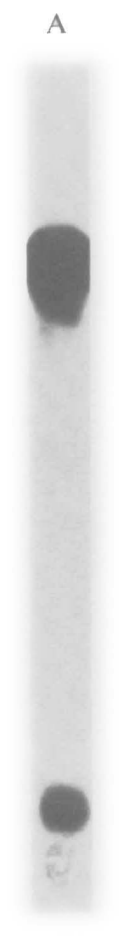

B

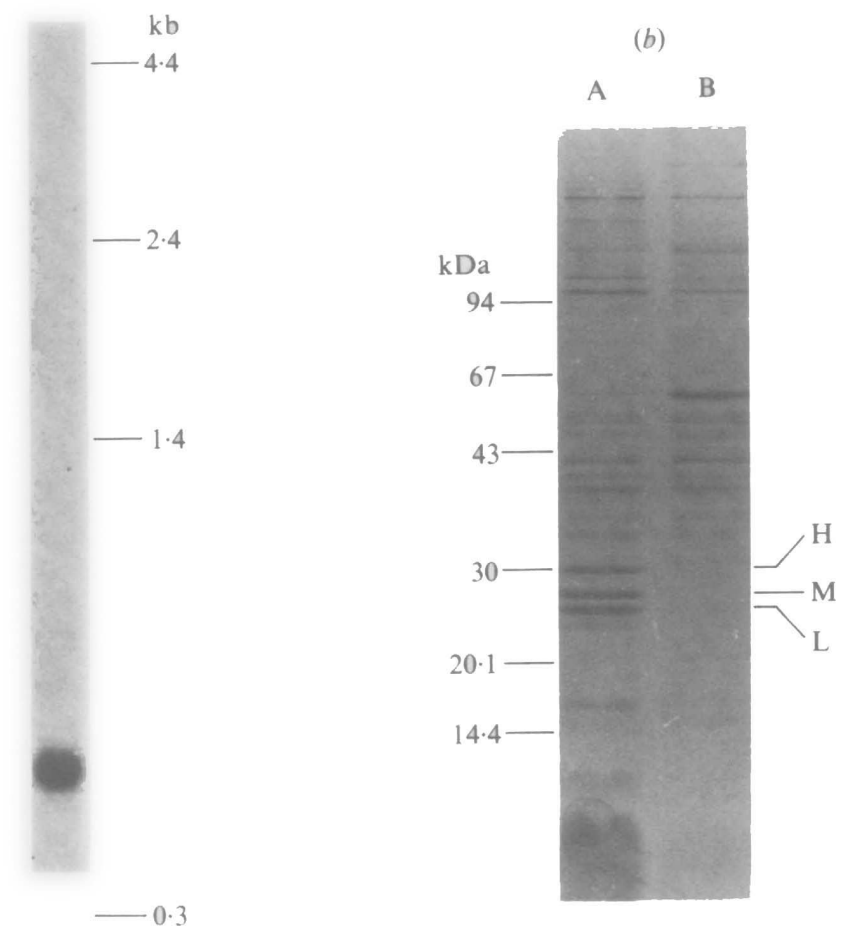

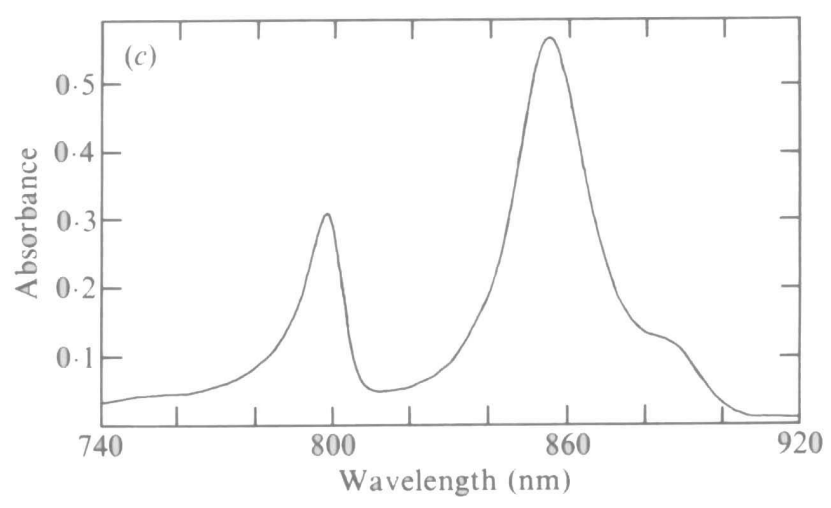

Fig. 2. Comparison of properties of mutant TNF9 and the wild-type of Rb. sphaeroides. (a) Northern blot of total RNA probed with pSRC2. Track A, wild-type; track B, TNF9. (b) SDS-PAGE of reaction centre polypeptides. The apparent molecular masses of protein standards are shown on the left, and the positions of the three reaction centre subunits $\mathrm{H}, \mathrm{M}$ and $\mathrm{L}$ on the right. Track $\mathrm{A}$, wild-type; track $\mathrm{B}$, TNF9. (c) Low-temperature absorption spectrum of membranes from mutant TNF9 (recorded at $4 \mathrm{~K}$ ).

Tn 5 was established by probing the Southern blot with pKan2, which contains the $3.5 \mathrm{~kb}$ HindIII fragment of Tn 5 cloned into pBR322 (see Table 1). No signal was detectable in the wildtype control, but in each of the mutants Tn 5 was detected. Through the use of $\mathrm{pJW} 1$ as a probe, it was established that $\mathrm{Tn} 5$ had inserted into the puf region. The elevation in size and the introduction of a new BamHI site can be seen by comparison with the wild-type control (Fig. 1, track A). Furthermore, Tn 5 contains four PstI sites (Jorgensen et al., 1979) and through the use of a $4.6 \mathrm{~kb}$ PstI subfragment of $\mathrm{pJW} 1$ as a probe, the sites of insertion of $\mathrm{Tn} 5$ were located (see Fig. 5: insertions 9, 10, 11 and 26). All four insertions map in the puf $L$ or $M$ genes; although 

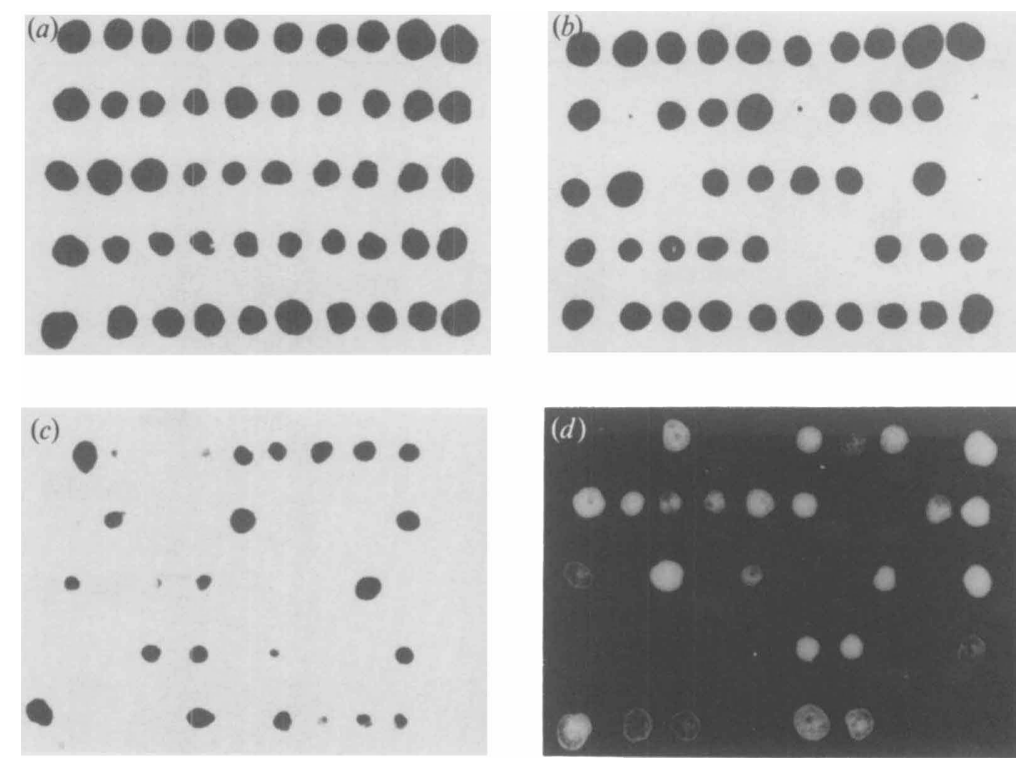

Fig. 3. Localized mutagenesis of pufL in $R b$. sphaeroides following transfer of $\mathrm{pSRC} 1:: \operatorname{Tn} 5: 9$ into the wild-type. Fifty colonies were toothpicked and analysed for $(a)$ aerobic growth, $(b)$ photosynthetic growth, $(c)$ presence of the pSUP202 'suicide' vector, using radioactively labelled pSUP202, and (d) enhanced fluorescence.

insertions into the puf $A$ and $B$ genes might be expected to yield a similar phenotype, none were found.

Northern blot analysis of one of these mutants, TNF9 (Fig. 2a), shows that the $2.6 \mathrm{~kb}$ transcript, which encodes the whole puf operon (Zhu et al., 1986), is absent as a result of Tn5 mutagenesis, and that the $0.5 \mathrm{~kb}$ transcript must arise independently of the larger transcript, in agreement with the findings of Zhu et al. (1986). In SDS-PAGE of membranes from mutant TNF9, $\mathrm{L}$ and $\mathrm{M}$ polypeptides of the reaction centre are no longer visible (Fig. $2 b$ ); the $\mathrm{H}$ subunit is also absent, which suggests that $\mathrm{L}$ and $\mathrm{M}$ are needed to stabilize $\mathrm{H}$. A $60 \mathrm{kDa}$ polypeptide is prominent in membranes from the mutant: its origin and function are unknown. The absorption spectrum recorded at $4 \mathrm{~K}$ (Fig. $2 c$ ) detects the presence of the pufB,A gene product - the lightharvesting antenna, B875, which is observed as a shoulder at approximately $884 \mathrm{~nm}$.

\section{Localized mutagenesis of pufL}

Random transposon Tn5 mutagenesis provides a useful tool for extending the genetic possibilities of $R b$. sphaeroides, and presents the further possibility of physical mapping of cloned DNA by 'localized' or 'site-specific' mutagenesis in which Tn 5 insertions are generated in fragments of $R b$. sphaeroides DNA cloned in $E$. coli and products of $\mathrm{Tn} 5$ transposition are mobilized into wild-type $R b$. sphaeroides. Homologous recombination between plasmid-borne and genomic sequences should result in the insertion of the $\mathrm{Nm}^{\mathrm{R}}$ marker into a defined region of the genome; the phenotype of this transconjugant will reflect the site of insertion of $\operatorname{Tn} 5$ in the cloned DNA. To test this process in $R b$. sphaeroides, genomic DNA from TNF9 was digested to completion with $E c o$ RI, and then ligated into the $E c o$ RI site of pAcYc184. The $16.9 \mathrm{~kb}$ fragment containing the $\mathrm{Nm}^{\mathrm{R}}$ determinant was selected for and subsequently recloned into the EcoRI site of pSUP202 to form pSRC1::Tn5:9. This construction was mobilized into wild-type $R b$. sphaeroides and $\mathrm{Nm}^{\mathrm{R}}$ transconjugants were obtained at a frequency of $1.3 \times 10^{-5}$ per recipient; taking into account the probable efficiency of mobilization $\left(10^{-1}\right)$, the overall frequency of recombination is probably in the order of $10^{-4}$. A comparison with the frequency of random $\operatorname{Tn} 5$ transposition $\left(10^{-5}\right.$, see Discussion) indicates that recombination events that arise from the presence of homologous sequences flanking $\mathrm{Tn} 5$ are more frequent than transposition. 


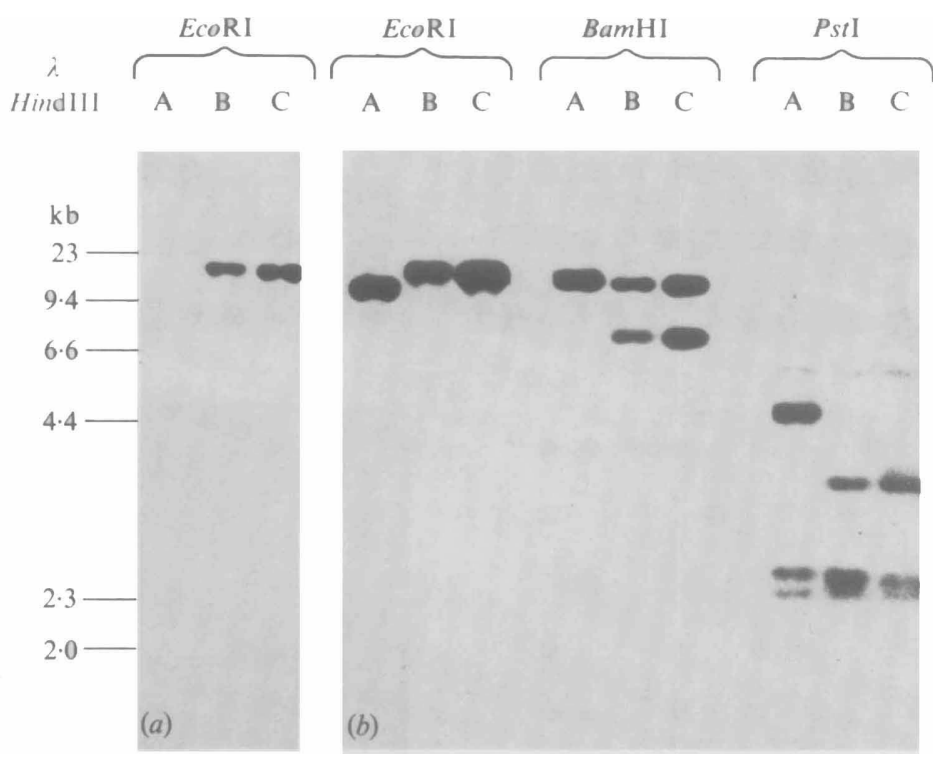

Fig. 4. Comparison of location of Tn5 in mutant strains TNF9 and TNF915, using Southern hybridization of genomic DNA. (a) Probed with pKan2; (b) probed with pJW1 (see Fig. 1). Tracks A, wild type; B, TNF9; C, TNF915. Strain TNF9 was isolated by random Tn 5 mutagenesis (see Figs 1 and 5 ); strain TNF915 was isolated following localized mutagenesis of $R b$. sphaeroides wild-type by pSRC1::Tn5:9.

Fifty transconjugants were selected at random and screened for their inability to grow photosynthetically, for the absence of the pSUP202 vector and for enhanced fluorescence (Fig. 3). Five possessed these properties, and had probably arisen as a result of a double crossover and marker exchange. Such a process should yield a duplicate of the original mutation (see below). Analysis of the remainder of the transconjugants is not straightforward. In the 25 cases where pSUP202 was detectable a single crossover had probably occurred, yielding heterogenotes with the normal capability for photosynthetic growth. Interestingly, almost half of these single crossover events perturbed the fluorescence properties of the photosynthetic apparatus to the extent that partially enhanced fluorescence was measured. In these cases transcription of puf genes is still possible, but the overall level of transcripts may have been reduced depending on the site of crossover and on polarity effects from $\mathrm{Tn} 5$. Some enhancement of fluorescence may be a consequence of a reduction in the number of reaction centre traps available to absorb energy from the light-harvesting system, although photosynthetic growth could be maintained. Finally, in several of the fifty colonies examined random $\operatorname{Tn} 5$ transposition may have occurred as with pSUP2021 earlier; this would lead to unpredictable effects on photosynthetic growth.

In order to verify that one of the $\mathrm{Nm}^{\mathrm{R}}$ transconjugants had resulted from marker exchange and had yielded the TNF9 genotype, genomic DNA from TNF915 was analysed by Southern hybridization (Fig. 4). A comparison of several digests indicated that the original site of Tn5 insertion in TNF9 has been established in TNF915, and that localized mutagenesis can be used in $R b$. sphaeroides.

\section{Construction of a physical map of puf genes using Tn5}

Localized Tn5 mutagenesis has found widespread use as a method of generating physical maps of genes in a variety of bacteria. Here the aim was to establish a means of generating multiple TnS insertions into plasmid-borne $R b$. sphaeroides DNA in $E$. coli and then, using the methodology described above, to examine the effect of these insertions on fluorescence and on photosynthetic growth. The starting point was pSRC2, a $7.2 \mathrm{~kb}$ BamHI-HindIII fragment containing the puf genes $A, B, L$ and $M$ cloned into pSUP202. This was transformed into $E$. coli 


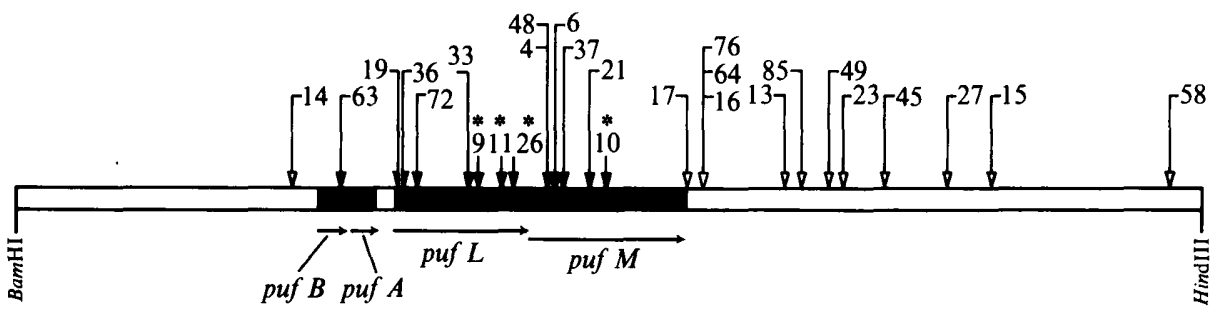

$1 \mathbf{k b}$

Fig. 5. Physical map of multiple sites of insertion of $\operatorname{Tn} 5$ into a region of $R b$. sphaeroides DNA bearing puf genes. Black arrowheads indicate $\mathrm{Tn} 5$ insertions which produce non-photosynthetic colonies when introduced by transposition or recombination into the wild-type genome. Open arrowheads indicate Tn5 insertions which produce a photosynthetic phenotype. Insertions $9,10,11$ and 26 , indicated by asterisks, were obtained by random $\operatorname{Tn} 5$ mutagenesis. All other insertions were produced by localized mutagenesis of pSRC2.

C600:: $\operatorname{Tn} 5$ and the products of $\operatorname{Tn} 5$ transposition into pSUP202 were mobilized triparentally into $E$. coli $\mathrm{HB} 101$ using $E$. coli DH1(pRK2073), while selecting for resistance to streptomycin $\left(500 \mu \mathrm{g} \mathrm{ml}^{-1}\right)$, ampicillin and neomycin. Eighty-six such transconjugants were used in triparental matings with the $R b$. sphaeroides wild-type, again using pRK2073. In ten cases Tn 5 had inactivated genes essential for photosynthesis, as judged by the inability of 20 to $50 \%$ of the pink, aerobically grown colonies to make the transition to brown, photosynthetically competent cells after transfer of the plates to an anaerobic jar. Such colonies were mostly highly fluorescent. Each point of insertion of $\mathrm{Tn} 5$ in $\mathrm{pSRC} 2$ responsible for this effect was estimated from BamHI, HindIII and BamHI + HindIII digests of mini-DNA preparations from HB101(pSRC2::Tn5) clones (not shown). The physical map is shown in Fig. 5. The coincidence between the known location of the puf genes $B, A, L, M$ and these Tn 5 insertions is clear; several more insertions are also shown which do not appear to disrupt genes essential for photosynthesis.

\section{DISCUSSION}

The frequency of transfer of the neomycin-resistance marker to $R b$. sphaeroides was approximately $2 \times 10^{-6}$ per recipient, a value which reflects the frequency of transfer, which is probably rather efficient (perhaps $10^{-1}$ per recipient), and the frequency of transposition, which could be $10^{-5}$ per recipient. If this latter process is completely random, unlike $\mathrm{Tn} 7$ transposition in $R$ b. capsulatus (Youvan et al., 1982), one may expect that the frequency of generation of highly fluorescent mutants is a function of that fraction of the genome encoding components essential for reaction centre assembly and function. The observed incidence is in approximate agreement with the size of the puh and puf genes, approximately $4 \mathrm{~kb}$ in total (Donohue et al., 1986; Zhu et al., 1986), relative to the size of the genome, approximately $4000 \mathrm{~kb}$.

The fact that Tn 5 insertions into genes other than $p u f B, A, L$ or $M$ may give rise to enhanced fluorescence is not unexpected since mutagenesis of the puhA gene, which encodes the reaction centre $\mathrm{H}$ subunit, may also yield reaction-centre-less mutants, due to destabilization of the LM complex in the membrane, for example. It is also possible that mutagenesis of genes encoding components of electron-transport pathways could perturb the fluorescence properties of the photosynthetic apparatus.

The methods described here can be applied to the location and mapping of other genes important in photosynthetic membrane assembly. In particular, the genes for the bacteriochlorophyll and carotenoid biosynthetic pathways (bch and crt genes) can be cloned using random transposon Tn 5 mutagenesis (M. Chaudri, S. A. Coomber \& C. N. Hunter, unpublished results).

The utility of localized mutagenesis is also established here; the number of double crossovers as a percentage of total recombinants is at least $10 \%$, which is sufficiently high to make this a useful genetic tool. Multiple insertions of Tn5 in cloned, plasmid-borne DNA can be used to generate physical maps, as in Fig. 5. Insertion of Tn5 appears to be random, since 10 out of 86 
clones bear inserts into puf genes, which represent approximately one-sixth of the total DNA in pSRC2. Selection for resistance to ampicillin and neomycin, and for mobility functions, will bias the experiment towards insertion of $\mathrm{Tn} 5$ into cloned $R b$. sphaeroides DNA rather than the vector. It is noteworthy however, that no insertions were mapped into the region up to $2 \mathrm{~kb}$ downstream from the BamHI site, although four or five might have been expected. Such results would have been of interest, in view of the presence of important regulatory sequences in this region of the $R b$. capsulatus genome (Bauer et al., 1987).

This technique presents exciting possibilities for the physical mapping of $b c h$ genes within cloned fragments isolated from a $R b$. sphaeroides gene bank (M. Chaudri, S. A. Coomber \& C. N. Hunter, unpublished results). Also, the availability of the cloned EcoRI fragment containing the Tn5 insertion from TNF9 permits the deletion of reaction centre function from an existing mutant, M21, which does not possess the light-harvesting complex B800-850. This leaves only the minor light-harvesting complex B875; the membranes from this mutant have provided a unique source of B875 antenna for biophysical studies (C. N. Hunter, R. van Grondelle \& R. J. van Dorssen, unpublished).

This work was supported by a grant from the Science and Engineering Research Council of Great Britain. The author gratefully acknowledges helpful advice from Professor John Beringer and Dr Michael Daniels, and the technical assistance of John Olsen and Andrew Rowell. He would also like to thank Rob van Dorssen for performing the low-temperature absorbance spectroscopy.

\section{REFERENCES}

Bauer, C. E., Eleuterio, M., Young, D. A. \& MARRS, B. L. (1987). Analysis of transcription through the Rhodobacter capsulatus puf operon using a translational fusion of puf $M$ to the $E$. coli lac $\mathrm{Z}$ gene. In Progress in Photosynthesis Research, vol. 4, pp. 699-705. Edited by J. Biggins. Dordrecht: Martinus Nijhoff.

Biel, A. J. \& MARRS, B. L. (1983). Transcriptional regulation of several genes for bacteriochlorophyll biosynthesis in Rhodopseudomonas capsulata in response to oxygen. Journal of Bacteriology 156, 686694.

Boyer, H. W. \& Roulland-Dussoix, D. (1969). A complementation analysis of the restriction and modification of DNA in Escherichia coli. Journal of Molecular Biology 41, 459-472.

De BRuIJN, F. J. \& LUPSKI, J. R. (1984). The use of transposon $\operatorname{Tn} 5$ mutagenesis in the rapid generation of correlated physical and genetic maps of DNA segments cloned into multicopy plasmids - a review. Gene 27, 131-149.

Chang, A. C. Y. \& Cohen, S. N. (1978). Construction and characterisation of amplifiable multicopy DNA cloning vehicles derived from the P15A cryptic miniplasmid. Journal of Bacteriology 134, 1141-1156.

CHORY, J. \& KAPLAN, S. (1982). The in vitro transcription-translation of DNA and RNA templates by extracts of Rhodopseudomonas sphaeroides. Journal of Biological Chemistry 257, 15110-15121.

Donohue, T. J., McEwan, A. G. \& KaPlan, S. (1986). Cloning and expression of the Rhodobacter sphaeroides reaction centre $\mathbf{H}$ gene. Journal of Bacteriology 168, 962-972.

ForNARI, C. S. \& KAPLAN, S. (1982). Genetic transformation of Rhodopseudomonas sphaeroides by plasmid DNA. Journal of Bacteriology 152, 89-97.

HaNaHan, D. (1983). Studies on transformation of Escherichia coli with plasmids. Journal of Molecular Biology 166, 557-580.
HUNTER, C. N. \& TURNER, G. (1988). Transfer of genes coding for apoproteins of reaction centre and lightharvesting $\mathrm{LH} 1$ complexes to Rhodobacter sphaeroides. Journal of General Microbiology 134, 14711480.

Hunter, C. N., Ashby, M. K. \& Coomber, S. A. (1987). The effect of oxygen on the levels of mRNA coding for reaction centre and light harvesting polypeptides of Rhodobacter sphaeroides. Biochemical Journal 247, 489-492.

JoRgensen, R. A., Rothstein, S. J. \& Reznikoff, W. S. (1979). A restriction enzyme cleavage map of Tn5 and location of a region encoding neomycin resistance. Molecular and General Genetics 177, 65-72.

Kaufmann, N., Hudig, H. \& Drews, G. (1984). Transposon Tn5 mutagenesis of genes for the photosynthetic apparatus in Rhodopseudomonas capsulata. Molecular and General Genetics 198, 153-158.

Kramer, H. J. M. \& AMEsz, J. (1982). Anisotropy of the emission and absorption bands of spinach chloroplasts measured by fluorescence polarization and polarized excitation spectra at low temperature. Biochimica et biophysica acta 682, 201-207.

LAEMMLI, U. K. (1970). Cleavage of structural proteins during the assembly of the head of bacteriophage T4. Nature, London 227, 680-685.

Leong, S. A., DitTa, G. S. \& Helinski, D. R. (1982). Heme biosynthesis in Rhizobium. Identification of a cloned gene coding for $\delta$-aminolevulinic acid synthetase from Rhizobium meliloti. Journal of Biological Chemistry 257, 8724-8730.

Nano, F. E., Shepherd, W. D., Watkins, M. M., KuHL, S. A. \& KaPLAN, S. (1984). Broad-host-range plasmid vector for the in vitro construction of transcriptional/translational lac fusions. Gene 34, 219-226.

Pemberton, J. M. \& Bowen, A. R. (1981). Highfrequency chromosome transfer in Rhodopseudo- 
monas sphaeroides promoted by broad-host-range plasmid RP1 carrying mercury transposon Tn501. Journal of Bacteriology 147, 110-117.

Simon, R., Preifer, U. \& PüHLER, A. (1983). A broad host range mobilization system for in vivo genetic engineering: transposon mutagenesis in Gram negative bacteria. Biotechnology 1, 784-791.

SISTROM, W. R. (1977). Transfer of chromosomal genes mediated by plasmid R68.45 in Rhodopseudomonas sphaeroides. Journal of Bacteriology 131, 526-532.

TAYlor, D. P., Cohen, S. N., Clark, W. G. \& Marrs, B. L. (1983). Alignment of genetic and restriction maps of the photosynthesis region of the Rhodopseudomonas capsulata chromosome by a conjugationmediated marker rescue technique. Journal of Bacteriology 154, 580-590.

Williams, J. C., Steiner, L. A., Ogden, R. C., Simon, M. I. \& FeHER, G. (1983). Primary structure of the M subunit of the reaction center from Rhodopseudomonas sphaeroides. Proceedings of the National Academy of Sciences of the United States of America 80 , 6505-6509.

Williams, J. C., Steiner, L. A., Feher, G. \& Simon, M. I. (1984). Primary structure of the $L$ subunit of the reaction center of Rhodopseudomonas sphaeroides. Proceedings of the National Academy of Sciences of the United States of America 81, 7303-7308.
Willison, J., Ahombo, G., Chabert, J., Magnin, J.-P. \& Vignais, P. (1985). Genetic mapping of the Rhodopseudomonas capsulata chromosome shows non-clustering of genes involved in nitrogen fixation. Journal of General Microbiology 131, 3001-3015.

Youvan, D. C., Elder, J. T., SANDlin, D. E., Zsebo, K., Alder, D. P., Panopoulos, N. J., Marrs, B. L. \& HeARsT, J. E. (1982). R-prime site directed transposon $\operatorname{Tn} 7$ mutagenesis of the photosynthetic apparatus in Rhodopseudomonas capsulata. Journal of Molecular Biology 162, 17-41.

Youvan, D. C., Hearst, J. E. \& Marrs, B. L. (1983). Isolation and characterisation of enhanced fluorescence mutants of Rhodopseudomonas capsulata. Journal of Bacteriology 154, 748-755.

ZhU, Y. S., Kiley, P. J., Donohue, T. J. \& KaPlan, S. (1986). Origin of the mRNA stoichiometry of the puf operon in Rhodobacter sphaeroides. Journal of Biological Chemistry 261, 10366-10374.

Zinchenko, V. V., BABYKIN, M. M. \& Shestakov, S. V. (1984). Mobilization of non-conjugative plasmids into Rhodopseudomonas sphaeroides. Journal of General Microbiology 130, 1587-1590.

ZSEBO, K. M. \& HEARST, J. E. (1984). Genetic-physical mapping of a photosynthetic gene cluster from $R$. capsulata. Cell 37, 937-947. 